\title{
Tactics as Empirical and Conceptual objects: Patient Activism and the Politics of Thalassaemia in Cyprus
}

\author{
THEODOROS KYRIAKIDES \\ UNIVERSITY OF MANCHESTER
}

\begin{abstract}
This article explores tactics as political technologies in the context of health and patient activism. It does so by exploring how the PanCyprian Thalassaemia Association-a thalassaemia patients association situated in Cyprus--opposed a medical rationing scheme imposed by the Cypriot government and managed to overturn the decision. I make the case that "tactics," for patient associations, are practices capable of rendering the political problematics of their illness visible to public and governmental perception, and propose four tactics by which the PTA was able to achieve such task. By putting the given event in conversation with STS and anthropological literature the article attempts to productively entangle tactics in their empirical and conceptual guises. This serves a two-fold purpose: That of putting together a repertoire of practices which patient associations can use to conduct politics, and that of facilitating connection between patient associations through these proposed practices. The article concludes with some more general considerations regarding an empirical-conceptual project on tactics.
\end{abstract}

\section{Keywords}

Cyprus; thalassaemia; politics of illness; patient activism; comparison; alliance; knowledge; action repertoire; strategy

. Theodoros Kyriakides, Email: theodoros.kyriakides@manchester.ac.uk

Copyright (C) 2016 (Theodoros Kyriakides). Licensed under the Creative Commons Attribution Non-commercial No Derivatives (by-nc-nd). Available at estsjournal.org. 


\section{Introduction}

Patient associations are becoming important actors in the decision-making of national governments and research agendas of scientific organizations (Landzelius 2006; Epstein 2007; Callon and Rabeharisoa 2008; Levitsky and Banaszak-Holl 2010; Koay and Sharp 2013). Although a seemingly positive development, the increasing political activity of patients can be linked to an intensifying entanglement of chronic illnesses with capitalist imperatives and neoliberal forms of governance. As several scholars have noted, the imbrication of illness with the capitalist nexus means that scientific research and the politics of illness often do not prioritize the needs of patients, but the interests of national governments and pharmaceutical companies (Sunder Rajan 2006; Cooper 2008; Petryna 2009; Rose and Rose 2013). Conditions of neglect for patients are accentuated in the European Union, where weakened state apparatuses and health care systems are increasingly subjected to monetary cuts and economic austerity. This holds especially true for Cyprus, the country on which this article focuses. The success of patient organizations in gaining a foothold amid such contested and precarious milieus suggests there is fertile ground in examining the tactics by which they manage to accrue political leverage and actively situate themselves in the politcal becoming of their illness.

In this article I would like to examine what practices can be understood as tactical in the context of politics of chronic illnesses-in their intentions as well as in their effects. My task is to explore such tactical activity in a Cypriot context, and at the same time provide further traction to the notion of tactics as a useful route scholars can pursue in the future. An emphasis on tactics implies that the political nature of illness must not be analytically assumed. Rather, of importance is pinpointing the problematic events and, reactive to such events, practices-i.e. tactics-deployed by patient organizations, which lead to the political dimensions of illness becoming discernible to the wider public. I suggest that tactical practices are those that not only make the politically problematic character of illness visible in public perception, but also grant those negatively affected the leverage to actively partake in its re-composition. In what follows I further develop this claim by exploring the involvement of the PanCyprian Thalassaemia Association (from now on PTA) - a collective of thalassaemia patients in Cyprus-with a medical rationing scheme imposed by the Cypriot state. ${ }^{2}$ More specifically, I describe a case study in which the PTA, faced with the governmental implementation of this potentially disastrous for patients' treatment scheme, managed to overturn the decision by contesting the Cypriot state on several fronts.

As indicated by its title, the article aims to engage tactics on an empirical and also conceptual front. Eduardo Viveiros de Castro recently argued that anthropologists should move beyond understanding their discipline as a descriptive "mirror of society," and instead undertake the "coproduction" of concepts with peoples and collectives commonly restricted to their gaze (Viveiros de Castro 2014: 40-42). Relevantly, Casper Bruun Jensen claimed that a dichotomy between the empirical and the conceptual is still deeply rooted in STS literature. Jensen advises

2 Thalassaemia is a recessive blood disorder prevalent in areas around the Mediterranean basin. For an over overview of thalassaemia in relation to global health issues see Dyson and Atkins (2011). 
that scholars should move beyond interpretative and observational methods used to reconcile the two, and instead embrace "an ethos of empirical and conceptual experimentation" (Jensen 2014: 208). Following these suggestions, the article uses the PTA case study as a starting point for entangling tactics in their empirical and conceptual guises in order to develop their political application.

The development of tactics as empirical-conceptual compounds and potential political tools is related to the second important objective of this article-that of exploring and facilitating connection between patient organizations. Steven Epstein recently argued that scholars writing on patient organizations and other health-related social movements should replace the bifurcation of "particularistic demands and universalistic initiatives" of such groups with "a more nuanced appreciation of real and potential pathways of influence across, and cooperation among, social movements of various sorts" (Epstein in press: 1-2). By thinking in the in-between of particular and universal processes of global politics of health, Epstein encourages scholars to go beyond using connection as a methodological tool--in other words as a comparative exercise of connecting and juxtaposing otherwise disparate health movements in order to elucidate similarities and divergences-and instead focus on the relations, practices and alliances through which connection is concretely facilitated between patient organizations and other political entities, and what the political effects of such connections are. A challenge subsequent to the one posed by Epstein would be to understand how scholars can contribute to this project of connectivity: By exploring connection as a reality of the PTA's political activities, and also aiming to act as a potential technology of connection itself, the article once again attempts to fruitfully entangle the empirical and the conceptual.

Before describing the case study, I briefly situate it in the longer historical trajectory of the PTA. This historical background is useful since it demonstrates how the socio-political landscape of thalassaemia in Cyprus has shifted through time, as well as how the objectives and tactics of the association have been reconfigured in accordance with political, social, and technological change. I then further explore the capacity of tactics in rendering the political character of illness visible to governmental and public perceptions, and provide four tactics by which the PTA managed to achieve this task. In addition, I explore what I perceive to be a useful distinction between "perpetual" and "particular" tactics. In the conclusion of the article I consider the extent to which the PTA case study can provide the foundation for a more general empiricalconceptual project on political tactics.

\section{A Brief History of the PTA}

The PTA was established in Cyprus in the mid-1960s by a group of parents whose children suffered from thalassaemia. Medical knowledge and public understanding of thalassaemia at the time was rudimentary. As a result, patients were treated with superstition and prejudice throughout rural communities in Cyprus (Book 1978). The association was put together with the objectives of ending social stigma. Another factor in the founding of the PTA was the necessity to gain political leverage and demand better medical provision from the newly founded Cypriot 
state. This was no easy feat, and on several occasions drastic measures had to be taken in order for the thalassaemic population to be heard. For example, in 1977 the PTA carried out a series of demonstrations that led to the Cypriot state introducing a free deferoxamine ${ }^{3}$ supply in its healthcare system. The association also played a part in founding a blood donation coordinating committee-a quasi-governmental body which, even today, accounts for collecting the majority of the blood required for the weekly transfusions of thalassaemic patients in Cyprus.

The PTA also exerted pressure on the state to implement a premarital certificate, an objective that was achieved in 1983. According to this, in order for couples to get married in Cyprus they must procure a certificate denoting that both spouses have been tested for the thalassaemia trait. Although the certificate indicates that both are aware of their carrier status, it does not divulge the results of the test (Cowan 2008). Certain key members of the PTA were also instrumental in the founding of the Thalassaemia International Federation (TIF) in 1986. TIF has its headquarters in the capital of Cyprus, Nicosia, and has grown into an umbrella organization consisting of over 80 thalassaemia patient associations from around the world. The result has been a global organization that, through an exchange of knowledge, policies and perspectives, strives to improve the lives of thalassaemia patients.

Patients who were too young to act as members of the association when it was first founded eventually began to take over from their parents. Nowadays the entire board of the association is patient-led. The association has achieved public visibility through a number of media; the chief members of the association often make appearances in media such as newspapers, television and radio. The annual thalassaemia week, established in 1976, is now a regular fixture. The educational week has the three-fold purpose of improving public awareness and knowledge of thalassaemia and promoting blood donation, raising funds required for the operation of the association, and running educational workshops for patients and medical practitioners regarding emerging therapeutic technologies of thalassaemia. The PTA has also established numerous alliances. It maintains a close relationship with the Cypriot Institute of Neurology and Genetics, a state-funded institute established in 1990. A research branch has been formed in the institute that aims to improve diagnostic and therapeutic methods for thalassaemia. In addition, in cooperation with a global cluster of laboratories, work is being done on developing a gene therapy that could prove to be the final cure to thalassaemia. More recently, the PTA made a pact with the newly established medical school in the University of Cyprus in order to promote research aimed at treating haemoglobinopathies in Cyprus and elsewhere.

\section{Recent Involvement in the Cypriot Politics of Healthcare Rationing}

In March 2013, the Cypriot International Monetary Fund (IMF) bailout took place. Shortly thereafter, members of the PTA expressed worry about how the austerity measures imposed by the IMF on the Cypriot economy would affect their treatment, which up to that point had been free. Cyprus is currently the only EU country that does not have a national health system in

${ }^{3}$ Deferoxamine is a chelating agent used to remove excess iron from the body. Excess iron accumulates in the bodies of thalassaemia patients due to repeated transfusions. 
place. Private healthcare is not feasible for the overwhelming majority of thalassamia patients due to the chronic nature of their illness and the expensive prices of their medication. This leaves them no other option but to depend on governmental healthcare arrangements for their treatment.

In January 2014, after I left Cyprus, a patient with whom I had been in touch throughout my fieldwork began forwarding me newspaper clippings from Greek and English newspapers. The clippings concerned a rationing scheme the Cypriot state was to implement. The drug to be rationed was called Exjade. Exjade is one of three long-term therapies available for treating thalassaemia. The other two methods are deferoxamine pills and dialysis pumps. All three methods serve the same purpose of injecting the body with deferoxamine, a chelating agent used to excrete iron overloads resulting from blood transfusions from the human organism. What differentiates Exjade from other deferoxamine pills is that it is easier to use, since patients only have to take one Exjade pill daily as opposed to the twelve pills normally required. Exjade is also more efficient in excreting excess iron from the human body and presents fewer side-effects of drowsiness and nausea. Likewise, Exjade is more efficient and convenient in comparison with the dialysis pump method, which requires the pump to be attached on patients' body for approximately twelve hours daily.

Exjade, however, is much more expensive than the two other therapies. Even after conceding to patient demands, the Cypriot state introduced Exjade in 2007 with certain conditions and restrictions. Whereas all patients in Cyprus receive their monthly dosage of deferoxamine pills and pumps for free, Exjade is reserved only for thalassaemia patients whose bodies display intolerance and do not respond to the two other forms of therapy. According to procedures set by the Cypriot state, before a doctor prescribes Exjade to a thalassaemia patient, the patient first has to be evaluated and approved by a governmental committee and then by a medical committee. The result of this dual audit process has resulted in a lengthy waiting list for those requiring the drug.

On 15 January 2014, several Greek and English newspaper articles were published saying that eleven thalassaemia patients had died since 2007, when Exjade was first introduced and regulated in Cypriot healthcare. They had reported on a claim traced to the PTA, whose impetus for making it came after the Ministry of Health began considering cutting down the list of patients being supplied with Exjade in Cyprus, from 76 to 64 . The claim about the deaths of the eleven thalassaeamia patients was made by the president of the PTA, a patient herself. According to her, the eleven deaths resulted because four patients had to wait too long to be included in the list of those to be supplied Exjade by the Cypriot government, while the other seven deaths happened while patients were already on the waiting list. The PTA president was quoted as saying that problems for Cypriot thalassaemia patients:

Started ever since 2007 when, because of the high cost of Exjade, the state set restrictions [to its supply]. According to these restrictions, and in contrast to the rest of the countries where prescription by a doctor is adequate to receive it, in Cyprus the drug is administered only to those who provide proof that they prove resistant to other means of therapy. 
In the same article, an emphatic heading reads, "Cyprus is Last." After the heading, statistical evidence is provided to demonstrate the lack in Exjade access and supply that thalassaemia patients in Cyprus face in relation to other countries in EU and elsewhere. According to the statistics, Cyprus is the country with the lowest percentage of patients being administered Exjade; in the US 52\% receive the drug, in the UK 33.3\%, in France 65\%, in Israel 48\%, in Greece $25 \%$, in Bulgaria 15\%, and in Cyprus 6\%. As the article proceeds to emphasize once more, in these other countries patients do not have go through ad-hoc committees and bureaucratic delays in order to receive the medicine (Panayi 2014).

The next day, on 16 January 2014, another article was published, this time in an Englishspeaking newspaper. Its first sentence reads, "The Health Ministry is doing its best to get medication to patients with thalassaemia and multiple sclerosis despite having its hands tied after it had its budget slashed by parliament" (Stevenson 2014). Another article, this time directly quoting the Cypriot Minister of Health said, "We shouldn't face the dilemma of being between human lives and economic matters, but these are the facts laid in front of us" (Panayi 2014b, my translation from Greek). This same article also said that the PTA opposed statements made by the Minister of Health regarding the deaths of the eleven patients. More specifically, the Minister declared that the eleven thalassaemia patients did not die because they weren't taking Exjade. According to him, after consulting the official records of the Thalassaemia Centre based in Nicosia, none of the eleven died because of iron overload but rather due to heart failure. Since Exjade is a drug specifically made to counter iron overload, and since none of them had this particular cause of death, to him this meant that the lack in the Exjade supply was not the crux of the matter. The PTA's response to this claim was that heart and organ failure are caused by iron overload, and that the death of the eleven patients must thus be considered as related to the lack of Exjade supply. To quote the PTA president on the given occasion, "thalassaemia patients undergo frequent blood transfusions in order to stay healthy. Transfusions cause a rise in the iron levels of the human organism and need to be excreted. The liver and the heart are the organs most affected by high iron levels. The eleven deaths were thus the result of iron overload" (Panayi 2004b, my translation).

The patient I was in contact with at the time also sent transcripts of press releases made by three members of the Cypriot Parliament--one from the ruling conservative party, one from a social democratic party and the other from a communist party. The three MPs likewise expressed their concerns regarding the lack of Exjade in Cypriot healthcare and called on the Ministry of Health to allocate the funds required for purchasing the drug. The MP of the ruling party, who sided with the PTA on numerous previous occasions, said that the appropriate proposal would be submitted to secure the funds and that in a time of economic crisis we must all take care that the rights and access of patients to medical provision are not hindered.

The skirmishes between the PTA and the Ministry of Health were taking place in relation to a wider political context of thalassaemia in Cyprus. The attention the PTA received after the death of the eleven patients overflowed to other issues. For example, another article, besides calling attention to the lack of Exjade supply, criticized the overall constant deterioration of the 
thalassaemia treatment system. As the article said, "The PTA reports that, while Cyprus was once considered a model and pioneer in treatment, recent developments in treatment are not implemented, while there has been a backward development in other dimensions of treatment" (Constantinou 2014, my translation). Other articles mentioned the firm grip unions of pharmaceutical companies have in the Cypriot economy. Cyprus is one of the countries with the most expensive drug prices in the world, thus further limiting the already inadequate governmental budget (Stylianou 2014). Another article said that thalassaemia patients in Cyprus were caught in the middle of "clan wars" between the Ministry of Health and the State Auditing Board (Panayi 2014b, my translation). Articles also touched on the Cypriot central blood bank not implementing nucleic acid testing on their blood supply and ignoring standardized European blood check protocols required under directive 2002/98/EC, the disruption in the scheduling of their weekly transfusions, and the lack of blood supply periodically faced by thalassaemia patients in Cyprus (Phileleftheros 2014).

The issue of Exjade rationing was partially resolved on the January 23 2014, when, after a meeting of the Cypriot Parliament, reports circulated that the Ministry of Health was to release 1.8 million euro in order to attend to the immediate needs of thalassaemia and multiple sclerosis patients (Christou 2014), while no cuts on existing lists of patients supplied with the drug would be made. The reports also said that the Cypriot parliament would meet again in two weeks in order to confer on a deal to increase the supply of Exjade, and also that an investigative committee would be put together in order to verify the exact causes of death for the aforementioned eleven thalassaemia patients (Paisanou 2014).

The spree of newspaper publications ended on January 29, when the Cypriot Minister of Health visited the central hospital in Limassol, the second biggest city in Cyprus. The Minister's visit took place a few days after thalassaemia patients being treated there started complaining that chemotherapy treatment for cancer patients also started being carried out in their section of the hospital. The concern is this case was that the immune systems of thalassaemia patients are weakest at the stage of transfusion, meaning that an unsanitary surrounding could potentially prove fatal. According to several newspaper articles, when the Minister visited the thalassaemia section of the clinic for the second time, the patients undergoing treatment at the time clustered around him and started shouting, and even shoving him. Shortly following the incident the Minister announced that he would attend to the demands of the patients by relocating the thalassaemia section to a new site. The PTA president reported that pushing and shoving was not the right approach to solving the matter, and that "The Minister of Health has consistently been attentive and supportive to the demands of thalassaemia patients" (Simerini 2014, my translation from Greek).

\section{Tactics as Political Tools}

The PTA's historical trajectory showcases the shifting socio-political process of thalassaemia in Cyprus. The PTA emerged as a reaction to issues that collectively affected thalassaemia patients in Cyprus in the 1960s and 1970s, namely social discrimination against patients of thalassaemia 
and poor treatment conditions. Throughout its history the PTA managed to transform the sociopolitical space within which thalassaemia was enacted in Cyprus. Over time, a shift in the composition of the association, from parents to patients, entailed that objectives were to be revised and rearranged in light of such changing membership. Through public sensitization they have managed to integrate thalassaemia as an acceptable condition in Cypriot society, and thalassaemia patients as rightful citizens (Heath et al., 2003; Rose and Novas 2005) who have claims to healthcare access and medical provision. In addition, the "enactment" (Mol 2002) of thalassaemia in Cyprus was also influenced by techno-therapeutic changes. Better, mobile methods of therapy, such as deferoxamine pills and pumps became available. In short, these advances meant that thalassaemia is no longer perceived as a deadly illness but rather as a chronic illness. As often put by patients, the objective for thalassaemia patients in Cyprus nowadays is not social acceptance or basic medical provision, but an improvement in their quality of life through better state healthcare and medical services.

As a result of these changes, the tactics used by the PTA have also been revised. As Epstein writes for AIDS activism in the United States, likewise for the PTA this was a trajectory by which thalassaemia patients in Cyprus "changed tactics appropriately in response to an evolving political environment and as the research trajectory, and their own understanding advanced" (Epstein 2007: 523). A different "taste in tactics" (Jasper 1997) thus developed. Once locally enacted practices of resistance, such as demonstrations and picketing, slowly gave way to a distributed network of institutional alliances and committees that are used to communicate with the Cypriot state and partake in national politics and the research agendas of local and international scientific bodies. In short, PTA tactics and politics are no longer enacted in-esse, but in-potentia-not only in relation to a particular existing situation, but also in potential anticipation of such situations.

The argument might be made that, at all times, illness is political. Yet, by perceiving illness as inherently political, one erases the challenge, necessity and efficacy of "doing" politics (Brown 2015: 7). Although illness is indeed inherently political in its ontological articulation and everyday enactment, the links between politics and illness only attain relevance and efficacy as long as they are elucidated and rendered visible in governmental and public consciousness. As Michel Callon points out, taking his cue from Bruno Latour's notion of matters of concern (Latour 2004), "matters of concern exist only if the concerned groups create them as such by making them visible and perceptible in the public sphere" (Callon 2005: 312). Put differently, a matter is only of concern if it is collectively understood as such. In this sense, the notion of tactics proposed in this essay can be connected to Jacque Ranciére's political project to rearrange the "partition of the sensible" (2010:36), as practices capable of shifting attention and action to issues that were already in existence, yet remained invisible to all those not affected by them. As Ranciére adds, "politics, before all else, is an intervention in the visible" (2010: 37). Or, as Claire Colebrook puts it, taking her cue from the tactical writings of Michel de Certeau and Michel Foucault, "a tactical economy is generated...by generating a different point of view, a different way of viewing" (Colebrook 2001: 557). Likewise, tactics for patient associations serve in rendering visible the political 
problematics of illnesses, and in promoting deliberative processes they aid in rethinking and reconstituting such problematics.

In what follows I pinpoint five tactics that the PTA deployed in order to overturn the decision of the Cypriot government. As mentioned in the introduction, my treatment of these tactics is not interpretative but what could be described as declarative and pragmatic. An obstacle one encounters in assessing tactics as particular to an event is disentangling them from the amalgamation of political, economic, social and technological circumstances in which the given tactics were simultaneously deployed, and justly distributing causality and efficacy to each one. I suggest that a more politically generative treatment of tactics is one that, although it initially situates them as specific to an event, in an "affirmative style" (Pignarre and Stengers 2011: 9), proceeds to declare and explore-even in precursory fashion-the potential of such tactics as universal tools of political transformation. In other words, my primary aim here is not to describe or evaluate the political tactics of the PTA but rather to use them as a starting point for putting together a "bag of tools" (Bailey 2001 [1969]: xiv)" that patient associations can use to conduct politics. Following Jensen's call for a "more sustained exploration of conceptual-empirical relations and their inventive potentials" (Jensen 2014: 192), my intention is to explore what connections can be fostered between the PTA case study and anthropological and STS literature, what empirical-conceptual envelopings emerge out of such connections, and what political potency these might carry. Such an endeavor is predicated on the idea that concepts are not merely representational but pragmatic devices that, if constructed and deployed correctly, can have palpable effects in the world (Deleuze and Guattari 1994).

Although separated for the sake of clarity, the five tactics presented below are overlapping and complementary in their effects and intentions. Certain tactics--more specifically, no. 3 and to an extent no. 4-do not directly refer to the PTA case study, but pertain to the PTA's historical trajectory and political activity as a whole. These tactics might not be directly related to a specific incident of PTA activism, but they aid in setting up a more general infrastructure of alliance and relationality that makes the deployment of the rest of the tactics possible. This is a distinction between perpetual and particular tactics, which I will also discuss.

\section{Counter-knowledge}

Casas-Cortés et al. write that social movements are "spaces and processes in which knowledges are generated, modified and mobilized" (2008: 20). Similarly, Rabeharisoa et al. (2014) coined the term "evidence-based activism" to describe how patients, through their everyday experience and embodiment of their illness, construct and articulate counterknowledges that are thus able to advise the faulty understanding of policy-makers, politicians and experts.

The deployment of such a plurality of knowledges, developed by patients, can serve as a tactic able of informing the politics of illness. In the newspaper excerpts provided above, the

- F.G Bailey's work of comparing the practices of political organizations in Western and non-Western settings can be very well perceived as the first attempt to formulate a general, pragmatic theory of tactics. Thank you to Giovanni da Col for bringing this to my attention. 
Cypriot Minister of Health claimed that the deaths of the eleven thalassaemia patients did not happen because of iron overload in the organism, but because of heart and organ failure. The PTA's response to the Minister of Health was that heart and organ failure are caused by iron overload in the human organism, and therefore the deaths of the eleven patients were indeed caused by insufficiencies in the Exjade supply. As Brown et al. write, this was an example where patients, "point to scientific evidence of causation" (2004: 56-57) in order to inform public policymaking. The standoff denotes two disparate and divergent regimes of knowledge by which thalassaemia patients and the Cypriot minister apprehend and experience illness. As Moreira puts it, the Minister was "'right' about the wrong kind of knowledge" (Moreira 2012: 314). Nevertheless, these two regimes of knowledge do not point to an irreconcilable opposition between them, but the need for further connection. Opposed to the lacking, incomplete knowledge of thalassaemia that the Minister had, the deployment of counter-knowledge by patients was able to confront his faulty assumption and serve in reversing the position of the Cypriot state on Exjade provision.

Counter-knowledge can also take place on a numerical level. As Vololona Rabeharisoa points out, the insight derived from the production of statistical knowledge can act as a form of counter-knowledge by facilitating a "politics of numbers" (Rabeharisoa 2008: 23). Although not contained in the above case study, a story given to me by a PTA member is exemplary. This had to do with a pay-per-visit scheme the Cypriot government was thinking of implementing in August 2013 in relation to thalassaemia treatment, which had until then been free. This decision was taken in light of economic austerity and the need to raise money in order to repay national debt. According to the scheme, each time thalassaemia patients visited their local treatment centers they would have to pay for each transfusion, as well as for each tablet of deferoxamine and the dialysis pump they received from their local treatment center. The PTA opposed the scheme even in its preliminary stages of consideration. They knew that paying for each of their chronic treatments would impose a heavy economic burden on them, which would make receiving adequate treatment even harder than it already was. In order to counter the scheme they conducted their own studies and presented estimates to the state of how much a patient would have to pay monthly. The estimates displayed the severity of financial hardship a typical thalassaemia patient would go through and, at the same time, showed that the scheme would ultimately be unable to respond to the urgent need of the Cypriot state to repay national debt. The association managed to negotiate the amount a patient has to pay for each tablet and pump to fifty cents and a cap of ten euros, which is the standard medication fee for the entirety of the state-led healthcare system, while transfusions and check-ups remained free.

\footnotetext{
"On another occasion the PTA conducted an analysis of the number of times transfusions had to be rescheduled in a given amount of time, and presented this data to the Ministry of Health in the form of statistics and charts. The study revealed the structural insufficiency at work, as well the negative impact it had in the daily lives of patients. Unfortunately the problem of a lacking blood supply and thus erratic transfusion schedule persists.
} 


\section{Comparison as a Survey of Possibility}

In their appraisal of patient associations as becoming increasingly important for politics of illness, Callon and Rabeharisoa write that "comparative studies would be useful for determining the extent to which national frames amplify or curb" (2008: 257) the potential for patients and their issues to become visible in the public sphere. Relevantly, in social anthropology comparison has traditionally been a descriptive method of juxtaposing disparate socio-political contexts. In such an endeavor, the challenge consisted in discerning the key values of such contexts and determining whether attempts at comparison were valid and productive (Goodenough 1980; Falk Moore 2005; Iteanu and Moya 2015). I suggest that while comparison as method could prove useful in discerning similarities and differences between national contexts of patient activism (e.g. Rabeharisoa et al. 2014), equally politically potent would be to explore how comparison is facilitated and deployed by patient associations across national and political milieus. Scholars could move beyond treating comparison as a methodological tool and additionally engage in a project of exploring tactics of comparison used by patients, as well as exploring political dynamics of alliance and relation by which such tactics accrue potency.

If our understanding of comparison shifts, from method to political tactics, the challenge for scholars and patients alike is to pinpoint the nexus of comparison and the political relevance of such relational spaces. In statements by the PTA president that were given to the press, comparison was often made between the arrangements regarding Exjade supply in Cyprus and arrangements in other European countries. These comparisons in return served to convey the lack of Exjade that Cypriot thalassaemia patients faced in relation to other countries in the EU. Comparison was also made between Cyprus and the rest of the countries in the EU in order to suggest that Cyprus is the only case in which proper EU blood checks have not yet been implemented by the state. Finally, patients engaged in diachronic comparison between time periods of the Cypriot thalassaemia treatment system, suggesting that it was more efficient and attentive to their needs in the past.

Tactics of comparison are important not only because they unveil irregularities and the potential of improvement in a certain national healthcare context, but also because they provide the impetus for politics. By isolating and juxtaposing specific political elements of urgency for patients, such as access to medical provision, comparison serves in multiplying perspectives of the possible (Toren 2002), thus further enhancing and enriching the space of political activity from which comparison tactics are deployed. Diachronic and synchronic processes of comparison are not abstract, ghostly juxtapositions independent of time and space, but rather enacted practices, which often require the maintenance of an organizational infrastructure of alliance and relationality for their deployment. In the case of the PTA, comparison was made possible through alliances of the PTA with journalists and media outlets. As Tiago Moreira writes, such media "expressed the unraveling of sociotechnical ties caused by institutional failure to take concerns

- I would like to thank the second anonymous reviewer for this point: Namely, that tactics of comparison do not juxtapose entire national contexts bur rather pick and isolate elements relevant to the issues faced. In this sense, the selection of the elements that are to be compared and connected could also be considered a tactical practice. This also resonates with something said to me by one of my informants: "We should be careful with whom we compare ourselves to," namely that the PTA should compare itself with countries and patient associations with similar political demands and predicaments. 
into account" (Moreira 2012: 320). If, like Moreira, I analyze this incident primarily using these newspaper clippings, it is because they were the channels through which tactics of comparison were deployed.

Furthermore, in tracing the articulations through which comparison is made possible, one must also recognize the statistical data on provision to Exjade, which discovered and demonstrated the comparison. Such statistically procured knowledge (see also tactic no. 1) forms a numerical nexus and an infrastructure of relationality, which facilitates the becoming-visible of insufficiencies that manifest in the in-between of healthcare arrangements-that is to say, insufficiencies that are relational in nature and which would not have become publicly visible if not for the act of comparison itself (Verran 2010).

\section{Autonomy from the state apparatus (to a certain extent)}

Although patient associations undeniably proceed and operate through a certain relation with the state, this does not exhaust their spectrum of political activity. Even in 1920s, philosopher and political theorist John Dewey went as far as to hint that the state is an outdated modality of governance. As he writes, "Emerging publics cannot use existing institutions because they are insufficient to address developing needs. Rather, existing institutions may be inimical to those new needs" (Dewey 2012 [1927]: 28). Noortje Marres, taking her cue from Dewey and also another pragmatist philosopher, and Dewey's adversary, Walter Lippmann, points out that the need for public participation and involvement emerges precisely from "issues that existing institutions cannot settle" (Marres 2007: 770). As Marteen Hajer aptly terms it, the relegation of state power amid uncertainty and socio-economic turmoil has resulted in an "institutional void" (Hajer 2003), where the state has developed the inability to respond to the needs of concerned groups. In such precarious milieus, politics of illness are not enacted through a dialogic relationship between state and patient organizations, but rather according a climate of instability where both states and patients are immersed in conditions of chronic uncertainty and precarity.

As Tiago Moreira writes, amid such conditions of prolonged uncertainty a "pragmatic balance" must often be achieved between governments and patients, "able to recognize the particular situation of persons whose lives are heavily dependent on clinical knowledge and therapeutic innovation while deploying a standardized impersonal assessment of the value of the technologies upon which those persons' lives depend" (2011: 1339). Nevertheless, in the case of countries struck by economic austerity such a pragmatic balance becomes potentially harder to achieve. "Lack of funds" - to recount the excuse given by the Cypriot Minister of Health—seems to have become a skeleton key for states in addressing demands of concerned patients. Take, for example, another statement by the Cypriot Minister of Health circulated in the media: "These are the facts laid out for us." In such way, political landscapes of illness become fossilized and rigid; no space is left for political negotiation, deliberation and contestation. 
Even though the Cypriot state eventually released funds required for the acquisition of Exjade, such a decision did not completely resolve the PTA's predicaments. Patient activism is often enacted in relation to more than one problematic. As mentioned in the case study provided, in addition to shortfalls in the Exjade supply, the PTA is also protesting against lack of blood and hospital space, and the proper EU blood checks that the Cypriot state has not yet implemented. From within this predicament, another "pragmatic balance" (Moreira) of what issues can be brought to the table and are worth fighting for must be achieved. In this case, however, such balance is not achieved between patients and states, but between patients and the array of problematics they face.

By remaining partially external to the state apparatus, patient organizations can acquire a degree of autonomy and political flexibility. If states are unable to respond holistically to their problems and demands then, for patient associations, this second type of balance is one of picking your battles and at the same time seeking alternative, non-state related sources of income that can address issues which the state cannot. As indicated throughout The PTA's historical trajectory, staying external to the state apparatus and maintaining a certain degree of autonomy entails constant searching for alternative funding sources in Cyprus and elsewhere. As already mentioned, the association has, since 1976, organized an annual awareness week aimed at raising awareness and funds for the association. On another occasion, the association applied for and received a grant from the European Economic Area Grant Scheme. The money from this scheme went to producing educational material for the public, the organization of workshops aimed at educating medical practitioners on the specifics of thalassaemia treatment, and the creation of an electronic database used for recording the medical history of each patient, which replaced previous hard-copy medical records.

\section{Alliance}

The political generativity of alliance as a general characteristic of patient activism must be emphasized. As Steve Epstein notes, although initially operating on a local or national level, the proliferation and increasing interconnections forged between patient associations facing the same concerns, albeit in different context and/or country, resulted in a network of "transnational alliances" (Epstein 2007: 501). In the case of thalassaemia organizations around the world, such international alliances manifests in the form of the Thalassaemia International Federation (TIF). Through events such as annual conferences, workshops, and also through various research initiatives, TIF acts as an important meeting point for thalassaemia patients. Such an extensive network of alliance situates patients as important actors in harmonizing EU healthcare regulation and practices, through what Rabeharisoa and O'Donovan deem to be a process of "Europeanization from below" (Rabeharisoa and Donovan 2014: 2). Like the example of the PTA's plea for proper EU blood checking regulations, the common standards and procedures advocated by patient meta-collectives, or at least the struggle to implement them as is the case

- The supply of Exjade would in fact not be acquired until four months later, in June 2014 (Psillides 2014). 
with the PTA, provide a terrain and infrastructure of conversation according to which the impetus for political action is provided, and an exchange of perspective and comparison is facilitated (see tactic no. 2).

The importance of tactical alliance must also be considered in relation to another attribute of activism, that of reactionary politics. For concerned groups such as patients associations, politics are not primarily enacted according to the "constant" of political ideology, but rather as a reaction to an emergent issue that negatively affects them. Similar to what Vololona Rabeharisoa writes with respect to neuromuscular diseases in France, the PTA's political trajectory can likewise be understood as "the fruit of historical contingencies" (2003: 2133). Unpredictable events such those involved in the PTA case study become loci of intense political activity: They provide the impetus for the activation of alliances that are otherwise dormant, and the assembly of collectives aimed at tackling and reconfiguring such problematics. As described in tactic no. 3, alliances forged and maintained among the PTA, journalists and media outlets were crucial in conveying the problem faced by PTA members to the wider public. Such alliances can be characterized as "demonic" in Eduardo Viveiros de Castro's sense of the term (2010: 236), since they are predicated no only on a principle of similarity (e.g. alliances with other patient organizations) but also on a principle of heterogeneity and disjunction (alliances with journalists, MPs, scientists, and so on). The fact that Cypriot MPs of diverging--even opposing-political orientations aligned themselves with the PTA once again conveys that politics as it pertains to illness supersedes traditional politics of representation, and is instead enacted according to a collective spirit of pragmatism and "experimentation" (Gomart and Hajer 2003; Latour 2004b) between patient organizations and their allies.

The space of alliance created and allowed by such forms of transient and pragmatic politics, enacted according to the specificity and gravity of circumstances, is one of porosity, relational heterogeneity and tactical possibility. The purpose of alliance amongst such heterogeneous collectives is likewise varied and multiple. For example, the nature of alliance fostered between the PTA and journalists is different than that with politicians and MPs. While alliances with the former allowed the PTA to become visible in the public sphere through the mobilization of media, in the case of the latter, alliances forged with such key individuals of diverse political capacity and alignment allowed patients to cut through the seemingly monolithic facade of the state. Caroline Gatt, in a conceptually impressive examination of tactical thinking, shows how small organizations, or even individuals, can influence larger governmental institutions by breaking them down into smaller "vectors," some of which they can recruit, and the rest of which they can oppose. As she writes, this tactic allows smaller organizations to partake in policy-making processes by populating the "interstices of decision-making" (Gatt 2013: 360) of larger political entities, such as national states. By taking advantage of "preexisting lines of cleavage" (Epstein 2000: 21) within the Cypriot state apparatus, and by forging and maintaining alliances with specific MPs aligned with their demands, they manage to incorporate their demands into state procedures. 


\section{The Relation between Perpetual and Particular Tactics}

On a general level, strategy is understood to be an overall course of action; tactics are actual practices undertaken in order to achieve such a course of action, and are thus influenced by particular circumstances and events (Clausewitz 2008: 74; de Certeau 2011: xix). In the context of this article, the "strategy" is making the problematics of illness discernible to the public and creating spaces of political deliberation and contestation. The tactics used to pursue such strategy are practices that I have described above. What this distinction of strategy and tactics does not take into account, however, is that in order for a strategy to remain plausible a certain infrastructure of practices and alliances must also be maintained. Unlike widespread conceptualizations of strategy giving way to tactics, I instead think it is more useful to perceive the political activity and tactical dynamics of patient organizations as a relation between perpetual and particular tactics. By replacing "strategy" with "perpetual tactics," we are able to better grasp and attend to the prolonged practices that provide infrastructures of relationality and alliance, which in turn allows politics to be conducted in times of need.

In the case study provided, the political space of thalassaemia in Cyprus was altered by events that were unpredictable in their manifestation, such as the Cypriot IMF bailout and the consequent measures of economic austerity. In order to react to such unfavorable conditions, the PTA had to mobilize its political reservoir of alliances with media outlets and Cypriot MPs. This network of alliances was in return used to deploy tactics of comparison and counter-knowledge that explicitly made visible the matter of concern currently faced by thalassaemia patients in Cyprus. Further, PTA's network of alliances also allowed it to maintain a degree of autonomy from the Cypriot state apparatus through communication and support by the Cypriot public, the acquisition of funds from non-governmental sources, and participation in scientific research.

\section{Conclusion}

In the case of patient associations, achieving and maintaining political relevance demands forging and preserving networks of alliance that can be activated in time of need. As explained, this implies that alliances are not necessarily visible all the time, but are rather mobilized and manifest during episodes of particular concern. A duality of tactics must thus be devised by patient associations: On the one hand, they must develop the capacity to foster and maintain an extensive network of alliances and modes of communicating with the public (tactics no. 3 and 4) which will, over time, allow them to accumulate and maintain political relevance. On the other hand, they must develop the capacity to utilize these networks to deploy tactics capable of rendering the political dimension of their illness discernible through processes of dissensus and deliberation (tactics no. 1 and 2). This, then, is the relation between perpetual and particular tactics: While the former provide a foundation of alliance and tactical possibility, the latter, through the former, are deployed in moments of particular gravity and urgency.

Given their different socio-political circumstance is it possible for the life-lessons and tactics of particular patient organizations to be used effectively by others? I suggest that although the context of the PTA certainly differs from that of other patient organizations, tactics can cut 
through socio-political difference and be implemented elsewhere, as well as otherwise. PTA tactics, although enacted according to dimensions specific to the Cypriot context, are also predicated on dynamics that are universal to politics, namely relationality and the power and leverage one can derive from correctly managing, organizing and deploying one's relations and alliances. As Stengers and Pignarre put it, this is not a claim of "generality" but, rather, a project of "complementarity" (Pignarre and Stengers 2011: 84). In other words, it is not a matter of claiming that associations operating in different locales can implement the same tactics, but of identifying the means by which political associations across differing contexts can connect to, inspire and empower one another through tactical mimesis and also social and political adjustment.

Epstein writes about how patient associations study the "strategies, or action repertoires of previous movements or organizations" (Epstein 2007: 507). During fieldwork I was often told how the successful history and current activity of PTA serve as model templates for other, newlyfounded patient organizations outside of Cyprus. Such connections and exchanges show that the political activity of one patient organization is capable of surpassing considerations that while particular to the given organization also overflow into the political arena of illness as a whole. In addition, the political momentum and organizational livelihood the PTA gains from international alliances showcases that implementation of political tactics is not restrained, but rather diffracted and even accentuated and intensified through connections fostered between different cultural and socio-political milieus.

I suggest that scholars could facilitate and enrich such project of political connectivity. The list of tactics provided in this article is by no means definitive. Compilation and comparison of tactics could serve as a technology of connection and tactical cross-fertilization, capable of providing the foundations for dialogue and alliance between patient organizations. Through the PTA case study I attempted to participate in the invitation to "imagine productive conversations across partially overlapping groups, alliances, and re-combinations of existing movements organizations" (Epstein in press: 6). I approached that task from several, complementary perspectives. For one, I documented alliances maintained by the PTA with patient organizations, individuals such as MPs and journalists, and other scientific, financial and governmental bodies in Cyprus and elsewhere. In addition, I explored how such networks of alliance are mobilized to deploy tactics used for rendering the political problematics of illness visible to the wider public. Finally, I put the tactics used by the PTA in dialogue with STS literature in order to further clarify their relational dynamics and strengthen their potential application.

The generativity evoked by such entanglements of the empirical and conceptual suggest some further implications for the way STS scholars think and write about tactics of patient organizations and social movements. If constructing and assembling a collection of tactics is better than assembling a collection of case studies, this is because connection in the case of the latter can only be methodological. On the other hand, a project of documenting tactics as they unfold in practice is also capable of conceptually problematizing and further enriching their capacity to participate in politics. Failure is certainly foreseeable, and even required for such project. An empirical-conceptual project on the political efficacy of tactics can be understood as 
"prototypical" since "it incorporates failure as a legitimate and very often empirical realization" (Corsín Jiménez 2014: 381). In other words, a project of tactics of connection and tactics-asconnection is premised on the idea that tactics are potentially connective in both their empirical and conceptual registers, and that dialogue between these two registers can further encourage and co-develop their effectiveness. To engage with tactics of patient organizations thus provides an account of dexterity and political urgency, both on empirical and conceptual fronts-a literature of tactics and at the same time a tactical literature on attaining political leverage.

\section{Acknowledgements}

I would like to thank the ESTS editors and reviewers for their comments and suggestions, which were immensely helpful in strengthening key points of the article. I would also like to thank my thesis advisors, Jeanette Edwards and Maia Green, and my thesis examiners, Soumhya Venkatesan and Maria Puig de la Bellacasa, for their attentive and supportive reading of my work. This research benefited from the 2015 Sutasoma Award from the Royal Anthropological Institute of Great Britain and Ireland.

\section{References}

Bailey, F.G. 2001. Stratagems and Spoils: A Social Anthropology of Politics. Boulder: Westview Press.

Book, P. 1980. Thalassemia: An Anthropological Study of 86 Patients and Their Families in Cyprus. PhD Thesis. University of Connecticut.

Brown, M.B. 2015. "Politicizing science: Conceptions of politics in science and technology studies." Social Studies of Science 45(1): 3-30

Brown, P., P. Zavestoski, S. McCormick, B. Mayer, R. Morello-Frosch and R.G. Altman. 2004. "Embodied Health Movements: New Approaches to Social Movements in Health." Sociology of Health and Illness 26(1): 50-80.

Callon, M. 2005. “Disabled Persons of All Countries, Unite!" In Making Things Public: Atmospheres of Democracy, edited by P. Weibel and B. Latour, 308-313. Cambridge, Massachusetts: MIT Press.

Callon, M. and V. Rabeharisoa. 2008. “The Growing Engagement of Emergent Concerned Groups in Political and Economic Life: Lessons from the French Association of Neuromuscular Disease Patients." Science, Technology \& Human Values 33(2): 230-261.

Casas-Cortés, M.I., M. Osterweil and D.E. Powell. 2008. "Blurring Boundaries: Recognizing Knowledge-Practices in the Study of Social Movements." Anthropological Quarterly 81(1): 17-58.

Christou, J. 2014. "Cash freed up for life-saving meds." Cyprus Mail, January 23 2014. Accessed November 24 2015. http://cyprus-mail.com/2014/01/23/cash-freed-up-for-lifesaving-meds/

Clausewitz, C. v. 2008. On War. Translated by M. Howard and P. Paret Oxford: Oxford University Press.

Colebrook, C. 2001. "Certeau and Foucault: Tactics and strategic essentialism." The South Atlantic Quarterly 100(2) 543-574. 
Constantinou, K. 2014. "Cries of despair from patients" (In Greek). Simerini. January 16, 2014. $\begin{array}{llcl}\text { Accessed } & \text { on } & \text { November } & 24\end{array}$ http:/ / www.sigmalive.com/news/local/91898/kravgi-apognosis-asthenon

Cooper, M. 2008. Life as Surplus: Biotechnology and Capitalism in the Neoliberal Era. Seattle: University of Washington Press.

Corsín Jiménez, A. 2014. "The prototype: More than many and less than one." Journal of Cultural Economy 7(4): 381-398.

Cowan, R. 2008. Heredity and Hope: The Case for Genetic Screening. Cambridge, Massachusetts: Harvard University Press.

Daniel, A. 2014. "Postponement of two weeks regarding deliberation on thalassaemia medication." Sigmalive, January 23, 2014. Accessed on February 5th. http:/ / www.sigmalive.com/lifestyle/health/94335/anavoli-sti-syzitisi-gia-tafarmaka-ton-thalassaimikon

de Certeau, M. 2011. The Practice of Everyday Life. Translated by S.F. Rendall. Berkeley and Los Angeles: University of California Press.

Deleuze, G. and F. Guattari. 1994. What is Philosophy? Translated by H. Tomlinson and G. Burchell. New York: Columbia University Press.

Dewey, J. 2012. The Public and its Problems: An Essay in Political Inquiry. Pennsylvania: Pennsylvania University Press.

Dyson, S. and K. Atkins. 2011. "Sickle cell and thalassaemia: Global health issues coming of age." Ethnicity and Health 16(4-5): 299-311.

Epstein, S. 2000. "Democracy, Expertise, and AIDS Treatment Activism." In Science, Technology, and Democracy, edited by D.L. Kleinman. Albany: SUNY Press.

Epstein, S. 2007. "Patient Groups and Health Movements." In The Handbook of Science and Technology Studies, edited by E. Hackett, O. Amsterdamaska, M. Lynch and J. Wajcman, 499-540. Cambridge, Massachusetts: MIT Press.

Epstein, S. In Press. "The Politics of Health Mobilization in the United States: The Promise and Pitfalls of 'Disease Constituencies.'” Social Science \& Medicine.

Falk Moore, S. 2005. “Comparisons: Possible and Impossible." Annual Review of Anthropology 34: $1-11$.

Gatt, C. 2013. “Vectors, Direction of Attention and Unprotected Backs: Re-specifying Relations in Anthropology." Anthropological Theory 13(4): 347-369.

Gomart, E. and M. Hajer. 2003. "Is that Politics?" in Social Studies of Science and Technology: Looking Back Ahead, edited by B. Joerges and H. Nowotny, 33-61. The Netherlands: Kluwer.

Goodenough, W.H. 1980. Description and Comparison in Cultural Anthropology. Cambridge: Cambridge University Press.

Hajer, M. 2003. "Policy without Polity? Policy Analysis and the Institutional Void." Policy Sciences 36(2): 175-195.

Heath, D., R. Rapp and K.S. Taussig. 2003. "Genetic Citizenship." In A Companion to the Anthropology of Politics, edited by D. Nugent and J. Vincent, 152-167. London: Blackwell.

Iteanu, A. and I. Moya. "Mister D.: Radical Comparison, values, and ethnographic theory." HAU: Journal of Ethnographic Theory 5(1): 113-136.

Jasper, J. M. 1997. The Art of Moral Protest: Culture, Biography and Creativity in Social Movements. Chicago and London: University of Chicago Press.

Jensen, C.B. 2014. "Continuous Variations: The Conceptual and the Empirical in STS." Science, Technology, \& Human Values 39(2): 192-213.

Koay, P. and R. Sharp. 2013. "The Role of Patient Advocacy Organizations in Shaping Genomic Science." Annual Review of Genomics and Human Genetics 14: 579-595. 
Landzelius, K. 2006. "Patient Organisation Movements and New Metamorphoses in Patienthood." Social Science E Medicine 62(3): 529-537.

Latour, B. 2004. "Why has Critique Run out of Steam? From Matters of Fact to Matters of Concern." Critical Inquiry 30(2): 225-248.

Latour, B. 2004b. "What Protocol for New Collective Experiments." In Experimental Cultures, edited by H. Schmindgen, 17-36. Berlin: Kadmos Verlag.

Levitsky, S and J. Banaszak-Holl (Eds). 2010. Social Movements and the Transformation of American Healthcare. Oxford: Oxford University Press.

Moreira, T. 2011. "Health Care Rationing in an Age of Uncertainty: A conceptual Model." Social Science \& Medicine 72(8): 1333-1341.

Moreira, T. 2012. "Health Care Standards and the Politics of Singularities: Shifting In and Out of Context." Social Studies of Science 37(4): 307-331.

Paisanou, E. 2014. "€1.8 release to cover lack in medication" (In Greek). Stockwatch. January 23 2014. Accessed $\quad$ November 2015. http:/ / www.stockwatch.com.cy/nqcontent.cfm?a_name=news_view\&ann_id=19058 3

Panayi, M. 2014. "11 thalassaemics died waiting for Exjade" (In Greek). Phileleftheros. January 15. Accessed on February 5th 2015. http://www.philenews.com/el-gr/koinoniaeidiseis / 160/180197/11-thalassaimikoi-pethanan-perimenontas-to-exjade

Panayi, M. 2014b. "Attack of thalassaemia patients on Minister" (In Greek). Phileleftheros. January 16, 2015. Accessed on November 24, 2015. http://www.philenews.com/el$\mathrm{gr} /$ koinonia-eidiseis/160/180410/tp--epes-t-aassa

Petryna, A. 2009. When Experiments Travel: Clinical Trials and the Global Search for Human Subjects. Princeton: Princeton University Press.

Phileleftheros. “Transfusion problems” (In Greek). January 16 2014. Accessed November 242015. http:/ / www.philenews.com/el-gr/koinonia-eidiseis/160/180577/ piata-enchou-tptta-tou-aat-sta-sea

Pignarre, P. and I. Stengers. 2011. Capitalist Sorcery: Breaking the Spell. Edited and translated by A. Goffey. Hampshire and New York: Palgrave Macmillan.

Psillides, C. 2014. "'Short-Sighted Policy on Thalassaemia,' say patients." Cyprus Mail. June 12, 2014. Accessed on November 30, 2015. http:// cyprus-mail.com/2014/06/12/ shortsighted-policy-on-thalassaemia-say-patients/

Rabeharisoa, V. 2003. "The Struggle Against Neuromuscular Diseases in France and the Emergence of the 'Partnership Model' of Patient Organisation." Social Science and Medicine 52(11): 2127-2136.

Rabeharisoa, V. and O. O'Donovan. 2013. “'Europe of patients, Europe for patients': the Europeanization of healthcare policies by European patients' organizations," CSI Working Papers Series 030, Centre de Sociologie de l'Innovation (CSI), Mines ParisTech.

Rabeharisoa, V., M. Callon, A.M. Filipe, J.A. Nunes, F. Paterson and F. Vergnaud. "From 'Politics of Numbers' to 'Politics of Singularisation': Patients' Activism and Engagement in Research on Rare Diseases in France and Portugal." BioSocieties 9: 194-217.

Rabeharisoa, V., T. Moreira and M. Akrich. 2014. “Evidence-based Activism: Patients', Users' and Activists' Groups in Knowledge Society." BioSocieties 9: 111-128.

Raberharisoa, V. 2008. "Experience, Knowledge and Empowerment: The Increasing Role of Patient Organizations in Increasing, Weighting and Circulating Experience and Knowledge." In The Dynamics of Patients Organizations in Europe, edited by M. Akrich, J. Nunes, F. Paterson and V. Rabeharisoa, 13-82. Paris: Presses de Mines. 
Ranciére, J. 2010. Dissensus: On Politics and Aesthetics. Edited and translated by S. Corcoran. London and New York: Continuum Press.

Rose, H. and S. Rose. 2013. Genes, Cells and Brains: The Promethean Promises of the New Biology. London: Verso Books.

Rose, N. and C. Novas. 2005. "Biological Citizenship." In Global Assemblages : Technology, Politics and Ethics as Anthropological Problems. Edited by A. Ong and S.J Collier, 439-463. Malden: Blackwell.

Simerini. 2014. "Furious with the Minister" (In Greek). January 29 2014. Accessed February 5 2015. http:// www.sigmalive.com/simerini/news/95972/orgismenoi-me-tonypourgo

Stevenson, P. 2014. "Drugs purchase delays causing havoc to thalassaemia and MS patients." The Cyprus Mail. January 16. Accessed on February 5th 2015. http://cyprusmail.com/2014/01/16/drugs-purchase-delays-causing-havoc-to-thalassaemia-andms-patients /

Stylianou, Maria. 2014. "Cyprus in 6 most expensive countries on medicine prices" (In Greek) Simerini. January 17, 2014. Accessed on November 242015. http:/ / www.sigmalive.com/simerini/news/92264/den-apedose-i-nea-timologiakipolitiki

Sunder Rajan, K. 2006. Biocapital: The Constitution of Postgenomic Life. Durham and London: Duke University Press.

Toren, C. 2002. "Comparison and ontogeny." In Anthropology, by comparison, edited by A. Gingrich and R.G. Fox, 186-203. London and New York: Routledge.

Verran, H. 2010. "Number as an Inventive Frontier in Knowing and Working Australia's Water Resources." Anthropological Theory 10(1-2): 171-178.

Viveiros de Castro, E. 2013. "Intensive Filiation and Demonic Alliance." In Deleuzian Intersections: Science, Technology, Anthropology, edited by C.B Jensen and K. Rödje, 219-254. New York: Berghahn.

Viveiros de Castro, E. 2014 Cannibal Metaphysics. Translated by Peter Skafish. Minneapolis: Univocal. 